\title{
Gynecological and Obstetrical Emergencies at the University Clinic of Gynecology-Obstetrics of the National Hospital Donka Guinea
}

\author{
Mamadou Hady Diallo"*, Fatoumata Bamba Diallo1, Massa Keita², Djénabou Binta Baldé1, \\ Alpha Boubacar Barry², Ibrahima Sory Baldé ${ }^{2}$, Telly Sy², Namory Keita ${ }^{1}$ \\ ${ }^{1}$ University Department of Gynecology-Obstetrics, National Hospital Donka, Conakry, Guinea \\ ${ }^{2}$ University Department of Gynecology and Obstetrics, National Hospital Ignace Deen, Conakry, Guinea \\ Email: *hadydiallo2002@yahoo.fr
}

How to cite this paper: Diallo, M.H., Diallo, F.B., Keita, M., Baldé, D.B., Barry, A.B., Baldé, I.S., Sy, T. and Keita, N. (2021) Gynecological and Obstetrical Emergencies at the University Clinic of Gynecology-Obstetrics of the National Hospital Donka Guinea. Open Journal of Obstetrics and Gynecology, 11, 1862-1874.

https://doi.org/10.4236/ojog.2021.1112173

Received: December 2, 2021

Accepted: December 28, 2021

Published: December 31, 2021

Copyright $\odot 2021$ by author(s) and Scientific Research Publishing Inc. This work is licensed under the Creative Commons Attribution International License (CC BY 4.0).

http://creativecommons.org/licenses/by/4.0/ (c) (i) Open Access

\begin{abstract}
Gynecological and obstetrical emergencies are found all over the world, especially in developing countries where women pay a heavy price for giving birth. They can occur at any time during pregnancy and outside of pregnancy often in a socio-economic context. The objectives of this study were to describe the sociodemographic characteristics and the maternal and fetal prognosis of gynecological and obstetric emergencies. Patients and Methods: This was a descriptive cross-sectional study with prospective data collection, conducted at the University Clinic of Gynecology and Obstetrics of the Donka National Hospital between June 1 and September 30, 2015. It involved all patients admitted to our department in emergency for a gynecological or obstetrical complaint. Results: We collected 361 cases of gynecological and obstetrical emergencies out of a total of 1779 consultations, i.e. a frequency of $20.29 \%$. Obstetrical emergencies were predominant with $91.41 \%$ and gynecological emergencies represented $8.59 \%$. The average age of patients was 29.5 with extremes of 14 and 47 . Nulliparous women were the most numerous (34.35\%). More than half of the patients did not attend school (52.08\%) and $56.70 \%$ were evacuees. Abdominopelvic pain and hemorrhage were the main reasons for consultation (54.29\% and 49.58\%). Admission diagnoses were dominated by acute fetal distress and hemorrhage in the last quarter of pregnancy $(52.3 \%$ and $36.01 \%)$. The caesarean section rate was high $(82.12 \%)$. Maternal and perinatal lethality rates were high (5.2\% and 30.3\%). Conclusion: Gynecological and obstetrical emergencies are a public health issue because of the severity of the prognosis they impose on the mother and child. Maternal and perinatal mortality was very high. The prevention of these serious emergencies must be done through good quality prenatal consultations. Laparoscopy equipment and staff training are necessary for a minimal inva-
\end{abstract}


sive surgery of gynecological emergencies.

\section{Keywords}

Gynecological Emergencies, Obstetrical, Donka, Guinea

\section{Introduction}

Gynecological and obstetrical emergencies are dramatic clinical situations involving the short-term vital prognosis of the mother and/or the foetus. They can occur at any time during pregnancy and often in an unfavorable socioeconomic context [1].

Pregnant women are at risk for obstetrical complications that are often unpredictable and often fatal. Cataclysmic rupture of an ectopic pregnancy is not uncommon in our setting. Prenatal screening for high-risk pregnancies does not identify all women who will experience the emergency, and women who are not identified as being in the high-risk groups may nevertheless present obstetrical complications during labor, and these have a guarded maternal and fetal prognosis. If the pregnancy is well managed, it leads to a live birth and constitutes for women a criterion of social valorization. However, for millions of women, the outcome of pregnancy can be fatal [2].

The WHO estimates that every year in the world at least half a million women die as a result of obstetric complications and 3\% of the approximately 120 million children born each year have fetal distress and about 90,000 of them die from this respiratory distress [3] [4].

Sub-Saharan Africa is the region of the world with the highest maternal mortality rate. Of 536,000 maternal deaths recorded, more than a half $(270,000)$ occurred in Africa [3] [5].

Several emergencies can therefore be encountered during pregnancy, delivery and postpartum [6].

Maternal mortality and stillbirth are the dramatic outcomes of these complications.

The objectives of this study were to describe the sociodemographic characteristics and the maternal and fetal prognosis of these emergencies.

\section{Patients and Method}

This was a descriptive cross-sectional study with prospective data collection, conducted at the University Clinic of Gynecology and Obstetrics of Donka National Hospital of the University Hospital of Conakry between June 1 and September 30, 2015. It involved all patients admitted to our department in emergency for a gynecological or obstetrical complaint.

Gynecological and obstetrical emergencies are dramatic clinical situations involving the maternal and/or fetal vital prognosis in the short term. 
We proceeded to an exhaustive recruitment of all patients admitted in emergency in gynecological or obstetrical consultation during the study period.

We included in this study all patients admitted for a gynecological or obstetrical emergency and managed in the department during the study period.

The study population consisted of all women admitted to the gynecology-obstetrics department of Donka National Hospital for an acute gynecological pathology or one that occurred during pregnancy, delivery, or within 42 days of delivery and for which a precise diagnosis and a treatment were necessary to preserve the vital maternal and/or fetal prognosis. We followed the patients from admission to discharge. Data were collected using a survey form. The variables studied were sociodemographic, clinical, therapeutic and prognostic characteristics. The data were entered and processed using the epi info version 7 software.

Results were presented in tabular forms, expressed as percentages and averages.

The study protocol was approved by hospital authorities and informed consent was obtained from participants.

\section{Results}

\subsection{Overall Frequency}

During the study period we collected 361 cases of gynecological and obstetrical emergencies out of a total of 1779 consultations, i.e. a frequency of $20.29 \%$.

\subsection{Specificity of the Emergencies}

Obstetrical emergencies largely dominated with $91.41 \%$ and gynecological emergencies represented 8.59\% (Table 1).

The average age of patients was 29.5 with extremes of 14 and 47 . The average parity was 1.9 with extremes of 0 and 11 years. Housewives and the uneducated were the most numerous. Most of our patients were married.

\subsection{Mode of Admission}

More than half of the patients were evacuated (56.70\%) compared to $43.3 \%$ who came on their own.

\subsection{Means of Transport}

The transfer was not medicalized in any of the $100 \%$ cases and was done by public transport or in a private car. No venous lines were taken.

\subsection{Prenatal Follow-Up}

More than half of the patients (53\%) received between 1 and 3 ANCs, $24.4 \%$ more than 4 ANCs and 22.3\% no ANC (Table 2).

In more than half of cases abdominopelvic pain was the reason for admission.

\subsection{General Condition at Admission}

The general condition was considered satisfactory in $84 \%$ of cases and poor in 
Table 1. Socio-demographic characteristics.

\begin{tabular}{|c|c|c|}
\hline Socio-demographic characteristics & Number & Pourcentage \\
\hline \multicolumn{3}{|l|}{ Age (years) } \\
\hline$<15$ & 1 & 0.27 \\
\hline $15-19$ & 55 & 15.23 \\
\hline $20-24$ & 105 & 29.08 \\
\hline $25-29$ & 86 & 23.82 \\
\hline $30-34$ & 67 & 18.56 \\
\hline $35-39$ & 39 & 10.8 \\
\hline $40-44$ & 6 & 1.66 \\
\hline$\geq 45$ & 2 & 0.55 \\
\hline $\begin{array}{c}\text { Average age: } 29.5 \\
\text { Average age }\end{array}$ & \multicolumn{2}{|l|}{ Extremes: 14 et 47} \\
\hline \multicolumn{3}{|l|}{ Parity } \\
\hline Nulliparous & 124 & 34.35 \\
\hline Primiparous & 82 & 22.71 \\
\hline Pauciparous & 88 & 24.38 \\
\hline Multiparous & 46 & 12.74 \\
\hline Large multiparous & 21 & 5.82 \\
\hline \multicolumn{3}{|l|}{ Socio-professional category } \\
\hline Housewives & 146 & $40.44 \%$ \\
\hline Liberal profession & 112 & 31.02 \\
\hline Secondary school and university students & 71 & 19.67 \\
\hline Civil servants & 32 & 8.64 \\
\hline \multicolumn{3}{|l|}{ Educational Level } \\
\hline Non educated & 188 & 52.08 \\
\hline Primary school level & 58 & 16.06 \\
\hline Secondary school level & 57 & 15.79 \\
\hline Higher education & 58 & 16.07 \\
\hline \multicolumn{3}{|l|}{ Marrital Status } \\
\hline Married & 337 & 93.35 \\
\hline Single & 24 & 6.65 \\
\hline
\end{tabular}

$16 \%$ of cases (Table 3 ).

Obstetrical emergencies were dominated by an acute fetal distress and hemorrhage in the last quarter of the pregnancy.

Gynecological emergencies represented $8.59 \%$ and were dominated by hemorrhagic abortions, followed by a cataclysmic rupture of the ectopic pregnan$\mathrm{cy}$, the hemorrhagic fibromyoma and the ovarian cyst torsion. 
Table 2. Distribution of patients by reason for admission.

\begin{tabular}{ccc}
\hline Reasons for admission & $\mathbf{N}=\mathbf{3 6 1}$ & $\%$ \\
\hline Abdominopelvic pain & 196 & 54.29 \\
Hemorrhage & 179 & 49.58 \\
Dizziness & 154 & 42.66 \\
Headache & 87 & 24.09 \\
Epigastric pain in bar & 38 & 10.52 \\
Pelvic pain & 30 & 8.31 \\
Loss of fluid & 27 & 7.48 \\
Tonicoclonic seizures & 25 & 6.92 \\
Nausea and vomiting & 5 & 1.38 \\
\hline
\end{tabular}

Table 3. Diagnosis on admission of patients.

\begin{tabular}{|c|c|c|}
\hline Diagnosis & Number $(\mathrm{N}=361)$ & $\%$ \\
\hline Obstetrical Emmergencies & 330 & 91.41 \\
\hline SFA & 190 & 52.63 \\
\hline HRP & 77 & 21.33 \\
\hline Placenta prævia & 40 & 11.08 \\
\hline Placenta previa & 13 & 3.6 \\
\hline Delivery hemorrhage & 9 & 2.49 \\
\hline Pelvic anomalies & 77 & 21.33 \\
\hline Eclampsia & 25 & 6.92 \\
\hline Severe pre-eclampsia & 25 & 6.92 \\
\hline RPM & 24 & 6.65 \\
\hline Pulsatile cord prolapse & 8 & 2.22 \\
\hline Pre-rupture syndrome & 8 & 2.22 \\
\hline DFP & 7 & 1.94 \\
\hline $\mathrm{J} 2$ retention & 6 & 1.66 \\
\hline Gynacological Emmergencies & 31 & 8.59 \\
\hline Ruptured EPs & 9 & 2.49 \\
\hline Abortions & 10 & 2.77 \\
\hline Hemorrhagic fibromyoma & 7 & 1.94 \\
\hline Ovarian cyst torsion & 5 & 1.39 \\
\hline
\end{tabular}

\subsection{Caesarean Section Rate}

We recorded 271 cases of caesarean sections out of 330 obstetrical emergencies, i.e. a rate of $82.12 \%$.

\subsection{Therapeutic Data}

In our series, $12 \%$ of patients were transfused for severe anemia. All patients re- 
ceived crystalloids (lactated Ringer's or isotonic saline), colloids (macromolecules) in $62.2 \%$ of cases. The antibiotic therapy was systematic in all patients, in most cases $1 \mathrm{~g}$ injectable ampicillin was associated with $500 \mathrm{mg}$ infusable metronidazole. Hypertensive attacks were treated with alpha methyldopa and injectable nicardipine. Magnesium sulfate was used to treat or prevent seizures in $43.6 \%$ of cases.

In addition to the caesarean section (82.12\%), an exploratory laparotomy was performed either for uterine rupture in $3.6 \%$ of cases, ectopic pregnancies in $2.49 \%$, hemorrhagic fibromyoma in $1.94 \%$, cyst torsion in $1.39 \%$. Eight hysterectomies for hemostasis were performed, i.e. $2.21 \%$ for the worsening of hemorrhage. Laparoscopy was not performed due to the lack of equipment.

Regarding the management of abortions, manual intrauterine aspirations were performed in $2.77 \%$ of patients. A uterine revision was necessary in $17.3 \%$ of cases.

The average length of hospitalization was 3.2 days with extremes of 1 and 17 days.

\subsection{Maternal Lethality Rate}

We recorded 19 cases of maternal death, i.e. a maternal lethality of 5.26\%. Causes of death were dominated by hemorrhage, 16 cases out of 19 , i.e. $84.21 \%$. Other causes were represented by complications of vasculorenal syndromes, 3 cases out of 19 , i.e. $15.79 \%$. All cases of death were related to obstetrical emergencies.

\subsection{Perinatal Lethality Rate}

The perinatal mortality was $30.3 \%$.

\section{Discussion}

\subsection{Frequency}

Gynaecological and obstetrical emergencies were frequent in our study. These emergencies were essentially obstetrical (91.41\%) with an acute fetal distress as the main entity in our setting, followed by last pregnancy quarter hemorrhage. This high frequency of gynecological and obstetrical emergencies in our series could be explained by the fact that the university clinic of gynecology and obstetrics of the Donka National Hospital is the largest hospital in the country intended to receive all the severe cases evacuated. by peripheral health structures and birthing centers in Conakry.

Our frequency is much higher than those observed in Togo (2.65\%) [7] and in Gabon (3.15\%) [8].

It is also higher than those observed in other studies [1] [9] [10] [11] [12]. The high proportion of obstetrical emergencies was due not only to the geographical location of Donka maternity hospital in relation to the 4 urban communes of Conakry, but also to the high number of complicated deliveries evacuated to the maternity hospital of Donka. Gynaecological emergencies represented 8.59\% 
and were dominated by haemorrhagic abortions, followed by the cataclysmic rupture of ectopic pregnancy, haemorrhagic fibromyoma and ovarian cyst torsion. These complications were mainly related to the late discovery of these various pathologies. All cases of ectopic pregnancy were received in a cataclysmic rupture picture with peritoneal flooding.

\subsection{Sociodemographic Characteristics}

The average age of patients was 29.5 with extremes of 14 and 47 . Tchaou B A et al reported an average age of $26.7 \pm 6.2$ with extremes of 15 and 45 [2].

For Kadima M C et al. the 20 - 35 age group was the target of obstetrical emergencies with $77.63 \%$ of cases, the average age was 29.19 [6].

For Samake et al. the average age was 26 with extremes of 15 and 44 [13].

Andriamudy C L et al. reported extremes of 15 and 48 with an average age of 29 [14].

Sépou A et al. found an average age of 24 with extremes of 13 and 60. In the latter study, gynecological pathologies were included [15].

The average gestational age was 2.9 with extremes of 0 and 12 .

For Samaké A et al., primiparous women represented $60.4 \%$ of the sample and multiparous women $39.51 \%$ for an average parity of 4 with extremes of 1 and 14 [13].

Tchaou B A et al. reported an average gestity of $3.2 \pm 12.16$ [2].

At the University Hospital of Brazzaville, admissions to gynecological and obstetrical emergencies were more represented by primiparous women (42\%) [16]. In their series, primiparity was associated with pre-eclampsia and eclampsia in most of the cases admitted.

In Benin, multiparous women (34.59\%) and primiparous women (27.83\%) were in the majority.

The high percentage of nulliparous and primiparous women among obstetric emergencies also confirms the notion of risk of gravidopuerperium in young women. It is in this group that a high frequency of vasculorenal syndromes and mechanical dystocia is observed. Thus, gravidopuerperium in this category of pregnant women is marked with obstetrical problems due to the immaturity and the inexperience of primiparous women on the one hand, and the fragility of the uterus of multiparous women on the other [9] [17] [18].

More than half of the patients were not educated (52.08\%). A high level of education would help to understand the usefulness of prenatal consultations in the detection and the prevention of complications. Early detection of EPs allows therapeutic actions to be taken to avoid cataclysmic rupture.

\subsection{Prenatal Consultations}

In $53 \%$ of cases, patients admitted for obstetrical emergencies received between 1 and 3 ANCs. Most pregnancies with obstetrical emergencies were poorly followed up. Prenatal consultations were not of good quality. 
This observation was also made in Gabon in Libreville where the average ANC was $2 \pm 1.8$ [12].

We note that most of these parturient with obstetrical emergencies did not receive any ANCs and showed up only during labor. Although prenatal monitoring is an effective preventive activity that improves the outcome of the pregnancy, the number of ANCs is not sufficient and quality must be added to improve the effectiveness of prenatal monitoring [1].

Clinically, abdominopelvic pain of the UC type and hemorrhage were the main reasons for consultation.

The diagnoses of severity on admission were mainly acute fetal distress and hemorrhage in the last quarter of the pregnancy.

For Tchaou B A et al., signs of clinical severity on admission were: hypertensive crisis (21.1\%), hyperthermia (12.3\%), anemia (11.2\%), shock (5.4\%), coma (3.8\%), seizures (1.4\%) and jaundice (1\%) [2].

\subsection{Therapeutic Data}

In terms of treatment, our patients received either a medical, an obstetrical or a surgical treatments or both or all three of them at the same time.

In the Tchaou B 17 series, 5\% of patients received transfusions for severe anemia and $60.2 \%$ of patients received vascular filling. Hypertensive crises were treated with Nicardipine in $12.2 \%$ of cases. Magnesium sulfate was used to treat or prevent seizures in $9.3 \%$ of cases. Three hundred and thirty-seven deliveries were performed, $53.4 \%$ by vaginal delivery and $46.6 \%$ by cesarean section. One case of caesarean section was followed by a hysterectomy for delivery hemorrhage due to uterine atony. In addition to cesarean sections, $12.9 \%$ of patients underwent laparotomy either for an extra uterine pregnancy (12.4\%) or for pelviperitonitis $(0.05 \%)$ [2].

\subsection{Maternal Mortality}

Maternal case fatality in our series was 5.2\%. Our rate was higher than the $2.63 \%$ reported by Kadima M C [6].

Our rate, although high, is lower than those found in other African countries: $13.08 \%$ in Mali [6], $13.11 \%$ in Togo [7], 5.79\% at the University Hospital of Bouaké in Côte d'Ivoire with uterine rupture [9].

The main causes of these deaths were related to hemorrhage. The poor general condition of patients, aggravated by the conditions of transfer, could be the explanation for the high rate of maternal mortality in our environment.

\subsection{Perinatal Mortality}

The perinatal prognosis was severe in our study (30.3\%). Indeed, this rate remains high compared to those of the authors: $15.44 \%$ at the CNHHU of Cotonou [12], 11.6\% at the CHU of Cocody of Abidjan [10].

It should be noted that higher rates are reported in the literature, particularly 
in the series of the maternity hospital of the Malagasy District where it was $51.57 \%$ [1] and in that of the regional hospital of Sokodé in Togo, 52.45\% with a very high prevalence of uterine rupture (83.33) and HRP (80\%) [7]. In Bouaké, the perinatal prognosis was catastrophic with $92.6 \%$ of fetal death during uterine rupture [9].

Our high rates of maternal and perinatal deaths could be explained not only by the poor health coverage of the country in quality emergency obstetric and neonatal care but also by the three delays leading to death.

We also note a poor organization of the referral.

\section{Limitations and Difficulties}

The closure of Donka National Hospital of the University Hospital of Conakry was our main difficulty.

\section{Conclusion}

Gynaecological and obstetrical emergencies are a real public health issue in our environment because of the severity of the prognosis they impose on mothers and children. The maternal and perinatal mortality was very high in our environment. The prevention of these serious emergencies must be done through good quality prenatal consultations, rigorous monitoring of labor (partogram) and timely evacuation to referral centers equipped with the required number and quality of equipment and staff, which is cruelly lacking in many medical facilities in developing countries. All efforts should be focused on increasing the capacity of health care providers to provide a quality pregnancy monitoring, early diagnosis of emergencies and referral of patients to appropriate centers in a timely manner for a rational management. Laparoscopic equipment and staff training are necessary for a minimal invasive surgery in gynecological emergencies.

\section{Conflicts of Interest}

The authors declare no conflict of interest.

\section{References}

[1] Solofomalala, G.D., Randriamalalaarijaona, R.T., Rasendramino, M.H., Ratsivalaka, R. and Canonne, F. (2007) Les urgences gynéco-obstétricales dans une Maternité de District Malgache. Revue tropicale de chirurgie, 1, 67-70

[2] Tchaou, B.A., Hounkponou, N.F.M., Salifou, K., Zoumenou, E. and Chobli, M. (2015) Les urgences obstétricales à l'hôpital universitaire de Parakou au Bénin: Aspects cliniques, thérapeutiques et évolutifs. European Scientific Journal, 11, 260272.

[3] OMS (World Health Organization) (2009) Rapport synthése du lancement du guide des recommandations pour la pratique clinique des soins obstétricaux et néonataux d'urgence en Afrique. Bamako, Mali, du 21 juillet 2009.

[4] Fourn, L., Lokossou, F.E.B. and Yacoubou, M. (2000) Mortalité maternelle évitable en milieu hospitalier dans un département au Benin. Médecine d'Afrique Noire, 47, 23-26. 
[5] Mafart, B.Y. (1996) Approche de la mortalité maternelle au moyen âge en Provence. Actes des 6é journées anthropologiques. Dossiers de documentation archéologique No 17, Centre National de rechercche sur la santé. édit, Paris .

[6] Kadima, M.C., Mumba, M.A., Biayi, M.J. (2015) profil et pronostic des urgences obstétricales en salle de travail de la maternité de Bonzola à Mbujimayi. Mali médical, 30, 65-73.

[7] Akpadza, K., Baeta, S. and Hodonou, A.K.S. (1996) Fréquence et pronostic de quatre grandes urgences médico-obstétricales au centre hospitalier régional de Sokode. Médecine d'Afrique Noire, 43, 593-595.

[8] Mayi-Tsonga, S., Meye, J.F., Tagne, A., Ndombi, I., Diallo, T., Oksana, L., Mendome, G. and Mounanga, M. (2007) Audit de la morbidité obstétricale grave (near miss) au Gabon. Cahiers d'études et de recherches francophones/ Santé, 17, 111-115.

[9] Kouakou, P., Djanhan, Y., Doumba, Y., Djanhan, L. and Ouatara, M. (2007) Les ruptures utérines: Aspects épidémiologiques et pronostic fœto-maternel à la maternité du CHU de Bouaké, édition CAMES-série A, Vol. 5, CAMES, cote d'ivoire

[10] Pete, Y., Ouattara, A., Koffi, N., Abhe, C., Sanou, J., Iteke, F. and Kane, M. (2012) Césariennes en urgence: Pronostic materno-fœtal au CHU de Cocody d'Abidjan. SARANF. RAMUR, 17, 65-73.

[11] El Bechir, M. and El Hafed, D.M. (2011) La prévalence de la césarienne à l'hopital régional de Zouerate. Université de Nouakchott, Nouakchott.

[12] Tshabu-Aguemon, C., Denakpo, J., Adisso, S., Mampassi, E. and De Souza, J. (2012) Mortalités maternelles et périnatales liées aux références obstétricales à la C.U.G.O du CNHU-HKM de Cotonou. SARANF. RAMUR, 17, 1-4.

[13] Samaké, A., Traore, S.O., Keita, M., Doumbia, S., Diallo, M., Konaté, M., Diarra, L., Maiga, M., Traoré, O.M., Traoré, M.A., Diakité, N., et al. (2020) Les évacuations sanitaires obstétricales dans un Hôpital de deuxième niveau de référence du district de Bamako. Health Sciences and Disease, 21, 96-99.

[14] Andriamady Rosoarimahandry, C.L., Rakotoarimanana, M. and Ranjalahy, R.J. (2000) Mortalité maternelle à la maternité de Befelatanana. Journal de gynécologie obstétrique et Biologique de la Reproduction, 29, 501-508.

[15] Sepou, A., Yanza, M.C., Nguembi, E., Dotte, G.R., Nali, M.N. (2000) Analyse des évacuations sanitaires en gynécologie obstétrique à Bangui, Centrafrique. Cahiers d'études et de recherches francophones/ Santé, 10, 399-405.

[16] Otiobanda, G.F., Mahoungou-Guimbi, K.C., Itoua, C., Ellenge Mbolla, F.B. and Soussa, R.G. (2012) Morbidité et mortalité gravido-puerpérale dans un service de réanimation polyvalente. SARANF. RAMUR, 17, 1-4.

[17] Tebeu, P.M., Major, A.L., Ludicke, F., Obama, A.M.T., Kouam, L. and Doh, A.S. (2004) Devenir de l'accouchement aux âges extrêmes de la vie reproductive. Revue médecine Liége, 59, 455-459.

[18] Boyoma, B.M. (2011) Etude de la fréquence des urgences obstétricales à l'hôpital général de référence de Kamina. Université de Kamina RDC, Kamina. 


\section{Fiche D'Enquete}

\section{I-Interrogatoire:}

Date d'entrée: ; Date de sortie:

1 -Age .ans

2-Résidence: a-Kaloum $\square \quad$ b-Dixinn $\square \quad$ c-Matam $\square \quad$ d-Ratoma $\square$

e-Matoto $\square \quad \mathrm{f}$ - Si autre (à préciser)

3-Niveau d'instruction: a-Néant $\square \quad$ b-Primaire $\square \quad$ c-Secondaire $\square \quad$ d-Supérieur $\square$

4- Profession: a-Ménagère $\square \quad$ b-Elève/étudiante $\square \quad c$-Fonctionnaire $\square$

$\mathrm{d}$-ménagère $\square \quad \mathrm{f}$-Autres (à préciser).

5-Statut matrimonial: a-Mariée $\square \quad$ b-célibataire $\square \quad$ c-Divorcée $\square \quad$ Veuve $\square$

6-Mode d'admission: a-Evacuée $\square \quad$ b-Venue d'elle-même $\square \quad$ c-Référence $\square$

Si évacuée; motif: 1-Dystocie $\square \quad$ 2-Hémorragie $\square \quad$ 3-Eclampsie $\square \quad$ 4-SFA $\square$

5-Hémorragie de la délivrance $\square \quad$ 6-Douleur pelvienne $\square \quad$ 7-GEU $\square$

8-Anémie sur grossesse $\square \quad 9$-Autres.................

Si venue d'elle-même ; motif: 1 -Hémorragie $\square \quad$ 2-Douleur pelvienne $\square$

3-Crise convulsive $\square \quad$ 4-Autres.

7-Support de référence: a-Partogramme $\square \quad$ b-Fiche d'évacuation $\square \quad$ c-Lettre $\square$ d-Sans documents

\section{II-Rubrique Antécédents:}

A-Antécédent médicaux: 1-HTA $\square \quad$ 2-Anémie $\square \quad$ 3-Bilharziose $\square \quad$ 4-Diabète $\square$

5-Tuberculose $\square \quad$ 6-Autres

B-Antécédents chirurgicaux: 1-Appendicectomie $\square \quad$ 2-Péritonite $\square \quad$ 3-Césarienne $\square$ 4-Myomectomie $\square$ 5-Curetage $\square \quad 6$-Autres................

C-Antécédent gynéco-obstétricaux: 1-Fibrome utérin $\square \quad 2$ 2-Salpingectomie $\square$

3-kystectomie $\square \quad$ 4-Infection générale $\square \quad$ 5-Avortement $\square \quad$ 6-Plastie tubaire $\square$

7-Malformation génitale $\square \quad 8$-Autres................

D-Gestité:

E-Parité:

F-Nombre d'enfant vivant:. enfant(s)

G-Nature de la grossesse actuelle: 1-Pathologique $\square \quad$ 2-Non pathologique $\square$

$\mathrm{H}$-Age gestationnel: SA

I-Nombre de CPN:....

III Plaintes à l'admission: Pelvialgie: a-Modérée $\square \quad$ b-Intense $\square \quad$ c-Très intense $\square$ III-a-Examen clinique:

A-Signes généraux: 1-Etat général: a-Bon $\square \quad$ b-Passable $\square \quad$ c-Altéré

2-Coloration des conjonctives: a-Colorés $\square \quad$ b-Hypocolorés $\square \quad$ c-Pâles $\square$

3-Température: .${ }^{\circ} \mathrm{C}$

4-Tension artérielle:. ..cmHg

5-Pouls:. .puls/mn

B-Examen obstétrical:

a-HU: $\mathrm{cm}$; b-CA: cm; c-PP: g; d-BCF: bat $/ \mathrm{mn}$

1-Examen au spéculum: Col sain: a- Oui $\square \quad$ b- Non $\square$

2-Toucher Vaginal: a-Dilatation incomplète $\square \quad$ b-Dilatation complète $\square \quad$ c-Col ferme $\square$ 
2-1-Métrorragie: a-Minime $\square \quad$ b-Moyenne $\square \quad$ c-Abondante $\square \quad$ d-Très abondante $\square$

e-Pas de métrorragie $\square$

B-Signes cardio-vasculaires: 1-Tachycardie: a-Oui $\square \quad$ b-Non $\square$

2-Etat de choc: a- Oui $\square \quad$ b- Non $\square$

C-signes neurologiques 1-Agitation: a-Oui $\square \quad$ b-Non $\square$

2-Obnubilation: a-Oui $\square \quad$ b-Non $\square$

3-Coma: a-Oui $\square \quad$ b-Non $\square$

D-Etat de la femme en travail:

1-Durée du travail: heure

IV Examens complémentaires:

1-Tx d'Hémoglobine en urgence: .g/dl

2-Groupage- rhésus en urgence: a-Oui $\square \quad$ b- Non $\square$

3-Echographie: préciser résultat (anomalie):.

V-Diagnostic: a-SFA $\square \quad$ b-Rupture utérine $\square \quad$ c-PPH $\square \quad$ d-HRP $\square \quad$ e-Dystocie $\square$ f-Hémorragie de la délivrance $\square \quad$ g-Lésion des parties molles $\square$ h-DFP $\square \quad$ i-Eclampsie $\square$ j-Présentation dystocique $\square \quad k$-Procidence du cordon $\square \quad$ l-GEU $\square$ m-Torsion de kyste $\square \quad$ n-Avortement $\square \quad$ o-Autres à préciser.

VI Modes thérapeutiques

A-Hémorragie de la délivrance:

1-Révision utérine $\square \quad$ 2-Examens sous valve $\square \quad$ 3-Transfusion sanguine $\square$

4-Perfusion de macromolécules $\square \quad$ 5-Administration d'utérotoniques $\square$

B-Lésion des parties molles: 1-Suture sous anesthésie $\square \quad$ 2-Perfusion de soluté $\square$

3-Transfusion sanguine $\square \quad 4$ : Suture sans anesthésie $\square$

C-Eclampsie: 1-Administration d'anticonvulsivant $\square \quad$ 2-Administration d'anti-hypertenseur $\square$

3-Césarienne $\square \quad$ 4-Réanimation $\square$

D-PPH: 1-Amniotomie $\square \quad$ 2-Perfusion d'ocytocine $\square \quad$ 3-Césarienne $\square$

E-HRP: 1-Amniotomie $\square \quad$ 2-Perfusion d'ocytocine $\square \quad$ 3-Césarienne $\square$

4-Accouchement par voie basse $\square$

F- SFA: 1-Forceps $\square \quad$ 2-Césarienne $\square$

G-GEU: 1-Laparotomie $\square \quad$ 2-Perfusion de soluté $\square \quad$ 3-Transfusion sanguine $\square$

H- Torsion de kyste: 1-Antalgique (préciser).

2-Laparotomie $\square \quad 3$ - Perfusion de soluté $\square$

I-Avortement: 1-Expulsion spontanée $\square \quad$ 2-Curage/curetage $\square \quad 3$ Administration d'ocytocique $\square$

VII- Evolution et pronostic:

A-Pour l'enfant: 1-Vivant $\square \quad$ 2-Mort-né $\square \quad$ 3-Décès néonatal $\square$

Si vivant, APGAR à la naissance:

1-Réanimé: a- Suites bonnes $\square \quad \mathrm{b}$-Décès néonatal $\square$

Si mort-né cause: $\mathrm{a}-\mathrm{SFA} \square \quad \mathrm{b}-\mathrm{RU} \square \quad \mathrm{c}-\mathrm{PPH} \square \quad \mathrm{d}-\mathrm{HRP} \square \quad$ e-Eclampsie $\square \quad$ f-Procidence $\square$ g-Présentation dystocique $\square$

B-Pour la mère vivante: a-Suites simples $\square \quad$ b-suites compliquées $\square$

1-Nature des suites de couche: a- Endométrite $\square \quad$ b-Anémie $\square \quad$ c-Septicémie $\square$

d-Thrombophlébite $\square \quad$ e- Suppuration + lâchage $\square \quad$ f-Péritonite $\square \quad$ g-Pelvipéritonite $\square$

2-Mère décédée, cause: a-Hémorragie $\square \quad$ b-Anémie $\square \quad$ c-Arrêt cardiaque $\square$ 
d-HTA et complication $\square \quad$ e-Septicémie $\square$

-Voie d'accouchement des mères décédées:

1-Voie basse $\square \quad$ 2-Voie haute $\square \quad$ 3-Avant accouchement $\square$

-Durée de l'hospitalisation en jour:..........................jour(s)

-Besoin de transfusion: 1 -oui $\square \quad$ 2-non $\square$

-Besoin satisfait: 1-oui $\square \quad$ 2-non $\square$

Si oui besoins satisfait en quantité par $\mathrm{ml}$ de sang:...........ml 